\title{
Combination therapy with prednisone and cyclophosphamide in a I4-year-old boy with pemphigus foliaceus - a case report
}

\section{Terapia skojarzona prednizonem i cyklofosfamidem w leczeniu pęcherzycy liściastej u I4-letniego chłopca - opis przypadku}

\author{
Magdalena Salińska', Kamil Trambowicz², Joanna Narbutt , Anna Woźniacka', Aleksandra Lesiak' \\ 'Department of Dermatology and Venereology, Medical University of Lodz, Poland \\ 2Students' Research Club at the Department of Dermatology and Venereology, Medical University of Lodz, Poland \\ 3'Department of Dermatology, Pediatrics and Oncologic Dermatology, Medical University of Lodz, Poland \\ 'Klinika Dermatologii i Wenerologii Uniwersytetu Medycznego w Łodzi, Polska \\ ${ }^{2}$ Studenckie Koło Naukowe przy Klinice Dermatologii i Wenerologii Uniwersytetu Medycznego w Łodzi, Polska \\ ${ }^{3}$ Klinika Dermatologii, Dermatologii Dziecięcej i Onkologicznej Uniwersytetu Medycznego w Łodzi, Polska
}

\section{CORRESPONDING AUTHOR/ ADRES DO KORESPONDENCJI: lek. Magdalena Salińska Klinika Dermatologii i Wenerologii Uniwersytet Medyczny w Łodzi pl. Hallera 1 90-647 Łódź, Polska tel.: +48 600473480 e-mail: madzia.wojtczak@gmail. com}

\begin{abstract}
Introduction. Pemphigus foliaceus is a dermatosis rarely occurring in the paediatric population.

Objective. To draw attention to diagnostic and therapeutic difficulties associated with pemphigus foliaceus.

Case report. A 14-year-old boy was admitted to our department with seborrhoeic crusts over the anterior and posterior surfaces of the chest and erythematous-infiltrative lesions in the axillary and popliteal fossae. Since histopathological examination revealed features of Darier's disease, acitretin treatment was initiated. No improvement was noted after 3 months. Another skin biopsy was obtained and immunologic tests were carried out. Based on the clinical manifestations and results of additional tests, juvenile pemphigus foliaceus was diagnosed. Prednisone therapy was initiated, however it failed to produce satisfactory improvement in skin lesions. Cyclophosphamide was added to prednisone, causing remission of the disease.

Conclusions. In patients with non-characteristic lesions who fail to respond to treatment it is advisable to extend diagnostics by immunologic tests. In the reported case combination therapy with prednisone and cyclophosphamide led to long-term remission, causing no adverse effects.
\end{abstract}

\section{STRESZCZENIE}

Wprowadzenie. Pęcherzyca liściasta jest rzadko spotykaną dermatozą w populacji dziecięcej.

Cel pracy. Zwrócenie uwagi na trudności diagnostyczne oraz terapeutyczne w pęcherzycy liściastej.

Opis przypadku. Chłopiec 14-letni zgłosił się do Kliniki z powodu zmian $\mathrm{w}$ postaci strupów łojotokowych zlokalizowanych na przedniej i tylnej powierzchni klatki piersiowej oraz zmian rumieniowo-naciekowych w obrębie dołów pachowych i podkolanowych. 
W badaniu histopatologicznym wykazano cechy choroby Dariera i włączono leczenie acytretyną. Po 3 miesiącach nie uzyskano poprawy. Ponownie pobrano wycinek skóry oraz przeprowadzono badania immunologiczne. Na podstawie obrazu klinicznego oraz wyników badań dodatkowych rozpoznano postać młodzieńczą pęcherzycy liściastej. Włączono terapię prednizonem, nie uzyskując satysfakcjonującej poprawy w zakresie zmian skórnych. Zdecydowano o dołączeniu cyklofosfamidu, co spowodowało remisję choroby.

Wnioski. W przypadku niecharakterystycznych zmian chorobowych i przy braku poprawy po stosowanym leczeniu wskazane jest uzupełnianie diagnostyki o badania immunologiczne. Terapia łączona prednizonem i cyklofosfamidem pozwoliła na uzyskanie długotrwałej remisji i uniknięcie działań niepożądanych.

Key words: pemphigus foliaceus, immunosuppressive therapy, Darier's disease, cyclophosphamide, paediatric patient.

Słowa kluczowe: pęcherzyca liściasta, leczenie immunosupresyjne, choroba Dariera, cyklofosfamid, pacjent pediatryczny.

\section{INTRODUCTION}

Pemphigus is an autoimmune disease of the skin and/or mucous membranes, characterized histopathologically by the formation of acantholytic bullae. The two main forms of the disease are pemphigus vulgaris (PV) and pemphigus foliaceus (PF). Pemphigus foliaceus-specific lesions are located in seborrhoeic areas, predominantly on the upper chest and back, and on the scalp. This form of pemphigus is not associated with mucosal involvement. Pemphigus foliaceus runs a chronic course and the general condition of patients is usually good [1].

The disease affects mainly adults in the fifth-sixth decade of life, however it may also occur in children or in the elderly. Pemphigus foliaceus is the most common form of pemphigus in children. Pemphigus foliaceus antigen is desmoglein 1 with a molecular weight of $160 \mathrm{kD}$. As in PV, a certain role in the aetiopathogenesis of PF may be attributed to drug intake, consumption of spices and UVB exposure [2].

The most important examination for the diagnosis of pemphigus is direct immunopathological evaluation of the skin or mucous membranes. It should be complemented by serum immunologic tests to detect the presence of pemphigus-type antibodies. An ELISA test may be used to determine the autoantibody profile $[2,3]$.

\section{OBJECTIVE}

The aim of the study is to draw attention to diagnostic and therapeutic difficulties associated with

\section{WPROWADZENIE}

Pęcherzyca jest autoimmunologiczną chorobą pęcherzową skóry i/lub błon śluzowych, histopatologicznie charakteryzującą się powstawaniem akantolitycznych pęcherzy. Wyróżnia się dwa podstawowe typy: pęcherzycę zwykłą (pemphigus vulgaris - PV) oraz liściastą (pempigus foliaceus - PF). Zmiany typowe dla PF lokalizują się w okolicach łojotokowych, przede wszystkim na skórze górnej części klatki piersiowej i pleców oraz skórze owłosionej głowy. W PF nie dochodzi do zajęcia błon śluzowych. Pęcherzyca liściasta ma przebieg przewlekły, a stan ogólny chorego jest zazwyczaj dobry [1].

Choroba dotyczy głównie osób dorosłych, w 5.-6. dekadzie życia, ale może się również zdarzyć u dzieci lub osób w wieku podeszłym. Pęcherzyca liściasta stanowi najczęstszą odmianę pęcherzycy u dzieci. Antygenem występującym w PF jest desmogleina 1 o masie cząsteczkowej 160 kD. W etiopatogenezie choroby, podobnie jak w PV, pewną rolę mogą odgrywać leki, przyprawy, ekspozycja na promieniowanie UVB [2].

Najważniejszym badaniem diagnostycznym dla rozpoznania pęcherzycy jest bezpośrednie badanie immunopatologiczne skóry lub błon śluzowych. Powinno być ono uzupełnione badaniami immunologicznymi surowicy, pozwalającymi na stwierdzenie obecności przeciwciał typu pemphigus. Zastosowanie metody ELISA umożliwia określenie profilu autoprzeciwciał [2, 3].

\section{CEL PRACY}

Celem pracy jest zwrócenie uwagi na trudności diagnostyczne oraz terapeutyczne w PF u dzieci na 
PF in children based on our own case study and literature data.

\section{CASE REPORT}

In 2013 a 14-year-old boy presented to the Department of Dermatology and Venereology in Lodz with cutaneous lesions persisting for three months. The lesions manifested as brown seborrhoeic crusts located on the anterior surface of the chest and upper back, and erythematous-infiltrative lesions in the axillary and popliteal fossae. The lesions were accompanied by moderate pruritus. No eruptions were identified on the mucous membranes. In addition, acne lesions typical for adolescence were seen on the skin of the face, chest and back. The family history for skin diseases was negative. Since the clinical manifestations were relatively uncharacteristic, a skin biopsy was obtained to perform a histopathological examination which revealed focal acantholysis in the upper epidermal layers and superficially arranged dyskeratotic cells (corps ronds). The findings suggested the diagnosis of Darier's disease. Treatment with acitretin at $10 \mathrm{mg} /$ day was initiated, however no clinical improvement was noted after 3 months (Fig. 1).

A decision was made to obtain a skin biopsy to repeat histopathological examination, and to perform immunologic tests. Pemphigus foliaceus was diagnosed based on the findings which included

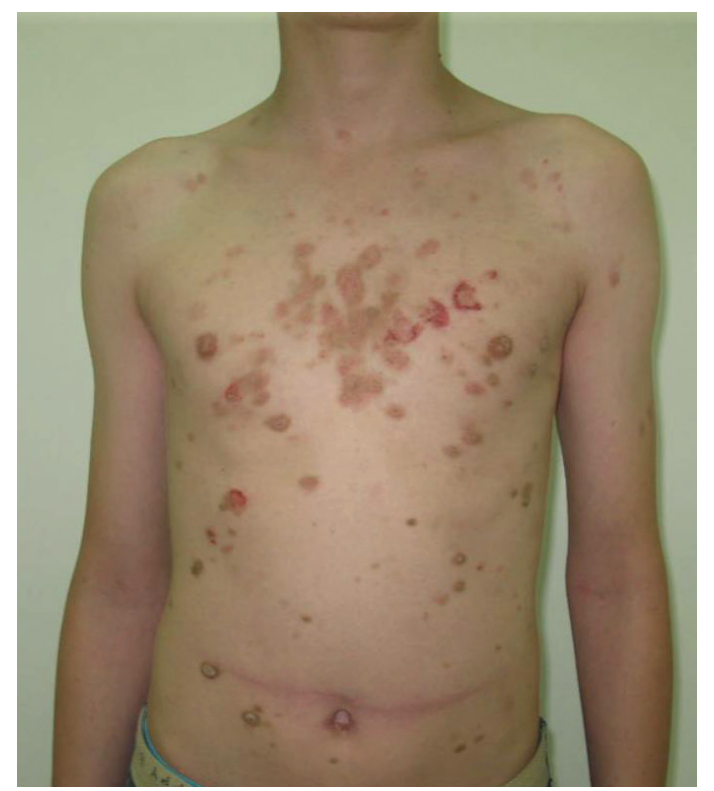

Figure I. Clinical lesions in the form of erosions and seborrhoeic crusts located on the anterior chest before immunosuppressive treatment

Rycina I. Zmiany kliniczne o charakterze nadżerek i tojotokowych strupów zlokalizowane na przedniej powierzchni klatki piersiowej przed leczeniem immunosupresyjnym podstawie przypadku własnego i danych z piśmiennictwa.

\section{OPIS PRZYPADKU}

W 2013 r. do Kliniki Dermatologii i Wenerologii w Łodzi zgłosił się 14-letni chłopiec, u którego od 3 miesięcy utrzymywały się zmiany skórne w postaci brunatnych, łojotokowych strupów zlokalizowanych na przedniej powierzchni klatki piersiowej i na górnej części pleców oraz zmiany rumieniowo-naciekowe w obrębie dołów pachowych i podkolanowych. Zmianom towarzyszył umiarkowany świąd skóry. Błony śluzowe były wolne od wykwitów chorobowych. Dodatkowo na skórze twarzy, klatki piersiowej i pleców obecne były wykwity trądzikowe charakterystyczne dla okresu młodzieńczego. Wywiad rodzinny w kierunku chorób skóry był ujemny. Ze względu na stosunkowo mało charakterystyczny obraz kliniczny pobrano wycinek skóry do badania histopatologicznego, w którym obserwowano akantolizę ogniskową w górnych partiach naskórka oraz powierzchownie ułożone komórki dyskeratotyczne (corps ronds). Wynik sugerował rozpoznanie choroby Dariera. Zdecydowano o leczeniu acytretyną w dawce $10 \mathrm{mg} /$ dobę. Po 3 miesiącach terapii nie uzyskano poprawy klinicznej (ryc. 1).

Podjęto decyzję o ponownym pobraniu wycinka skóry do badania histopatologicznego oraz przeprowadzeniu badań immunologicznych. Na podstawie wyników rozpoznano pęcherzycę liściastą: pęcherz

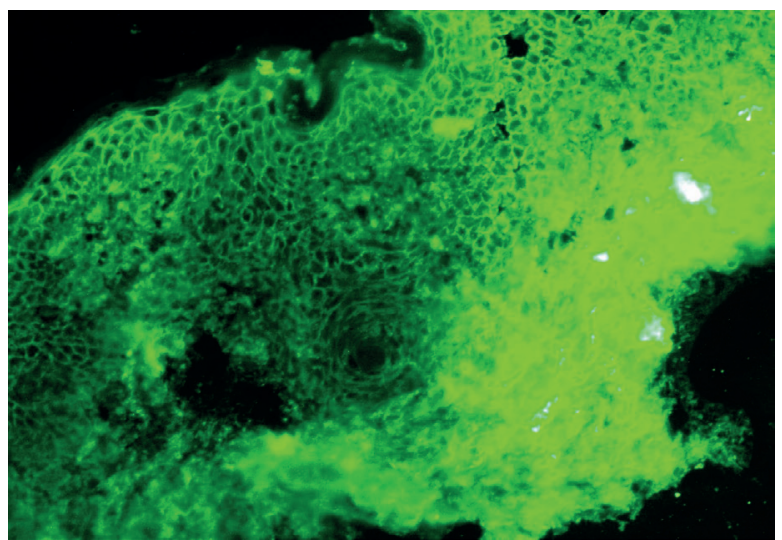

Figure 2. Immunopathological evaluation: IgG deposits in the intercellular spaces of the epidermal spinous layer

Rycina 2. Badanie immunopatologiczne - złogi lgG w przestrzeniach międzykomórkowych warstwy kolczystej naskórka 


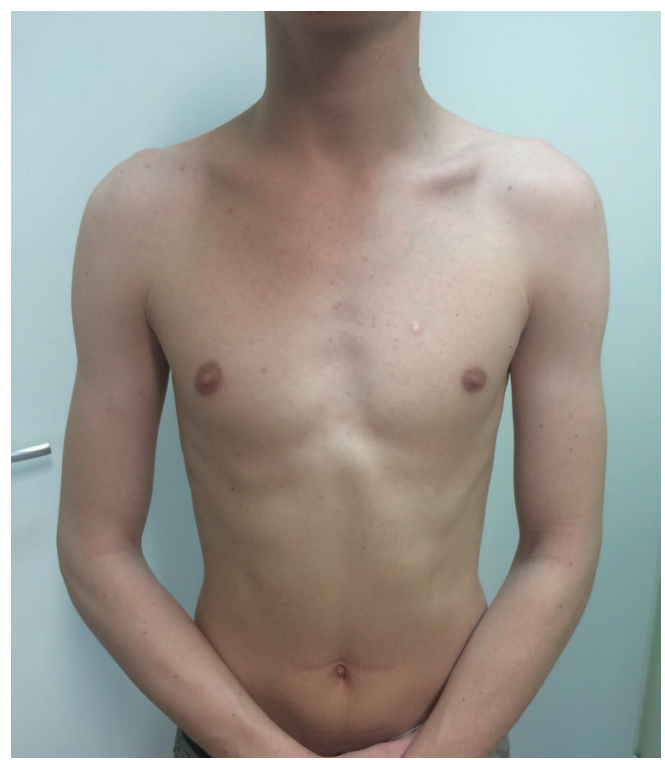

Figure 3. Complete clinical remission after the end of treatment

Rycina 3. Całkowita remisja kliniczna - stan po zakończeniu leczenia

histopathologically confirmed intraepidermal bulla and acantholysis, IgG $(+++)$ deposits in the intercellular spaces of the spinous layer shown by direct immunofluorescence (DIF) (Fig. 2), and circulating pemphigus-type antibodies (IIF) with a titre of $1: 160$ revealed by indirect immunofluorescence (IIF). Based on the clinical features and results of additional tests, juvenile pemphigus foliaceus was ultimately diagnosed. Oral prednisone treatment at $60 \mathrm{mg} /$ day was started. The dose was reduced to $50 \mathrm{mg} /$ day after a month. Partial clinical response was observed after 2 months of glucocorticosteroid treatment. The dose was reduced to $40 \mathrm{mg} /$ day, however within a month the skin lesions deteriorated. Taking into account the boy's age, the risk of adverse effects associated with high doses of glucocorticosteroids and the lack of satisfactory response to the treatment thus far, it was decided to combine glucocorticosteroids with immunosuppressive drugs. Intravenous immunoglobulin infusions and rituximab therapy were considered, however since there was no possibility of funding such treatment, cyclophosphamide at $50 \mathrm{mg} /$ day was added to therapy. Combination treatment with prednisone and cyclophosphamide improved the clinical condition of the skin. Remission of the disease was observed 3 months after the start of combination treatment. The doses of prednisone were gradually reduced but the skin lesions did not recur. The therapy was withdrawn after 11 months of using cyclophosphamide at gradually reduced doses, when all immunopathological findings were negative (Fig. 3). The patient is śródnaskórkowy oraz akantoliza w badaniu histopatologicznym, w badaniu immunofluorescencji bezpośredniej (DIF) złogi immunoglobulin IgG (+++) w przestrzeniach międzykomórkowych warstwy kolczystej (ryc. 2) oraz w immunofluorescencji pośredniej (IIF) - krążące przeciwciała typu pemphigus w mianie 1 : 160. Na podstawie obrazu klinicznego oraz wyników badań dodatkowych ostatecznie rozpoznano postać młodzieńczą pęcherzycy liściastej. Rozpoczęto terapię prednizonem p.o. w dawce $60 \mathrm{mg} /$ dobę, po miesiącu dawkę zredukowano do $50 \mathrm{mg} /$ dobę. Po 2 miesiącach leczenia glikokortykosteroidami uzyskano częściową poprawę kliniczną. Zdecydowano o zmniejszeniu dawki do $40 \mathrm{mg} /$ dobę, jednak po miesiącu nastąpiło pogorszenie. Ze względu na wiek dziecka i ryzyko wystąpienia działań niepożądanych związanych z dużymi dawkami glikokortykosteroidów oraz brak satysfakcjonującego efektu dotychczasowego leczenia zdecydowano o skojarzeniu glikokortykosteroidów z lekami immunosupresyjnymi. Rozważano dożylne wlewy immunoglobulin lub terapię rytuksymabem, lecz ze względu na brak możliwości finansowania takiego leczenia zdecydowano o dołączeniu cyklofosfamidu w dawce $50 \mathrm{mg} /$ dobę. Terapia łączona prednizonem i cyklofosfamidem spowodowała poprawę stanu klinicznego skóry, a po 3 miesiącach leczenia nastąpiła remisja choroby. Stopniowo zmniejszano dawki prednizonu i nie obserwowano nawrotu zmian skórnych. Terapię zakończono po 11 miesiącach stosowania cyklofosfamidu w zmniejszających się dawkach, po uzyskaniu całkowitej negatywizacji badań immunopatologicznych (ryc. 3). Pacjent ma obecnie 
now 17 years old and reports regularly for follow-up examinations to the Dermatology Outpatient Clinic. As of March 2016, there was no recurrence of lesions typical of PF.

\section{DISCUSSION}

Pemphigus foliaceus in children is a rare disease which may cause diagnostic and therapeutic difficulties. Owing to the superficial nature of the bullae, the clinical manifestations are dominated by erythematous exfoliative lesions and shallow erosions, which is why conditions such as contagious impetigo and seborrhoeic dermatitis are included in the differential diagnosis [4]. Histopathological features beyond the edge of the bulla often include fissures in the granular layer containing acantholytic cells with strongly stainable pyknotic nuclei reminiscent of granules in Darier's disease. Inflammatory infiltrations in the dermis are minor, and consist predominantly of leukocytes, partially eosinophilic [5] In the reported case the histopathological findings were difficult to interpret. Initially, Darier's disease was diagnosed on their basis. The repeat skin biopsy revealed the presence of acantholysis and parakeratosis, dilatation of the papillary vessels with epidermal thinning over the papillae, and aggregation of neutrophils in the exudate on the surface with focally identifiable separation of the upper epidermal layers, suggestive of the diagnosis of PF. The disease was finally confirmed on the basis of results of immunologic tests.

First-line drugs in the treatment of PF are glucocorticosteroids. The doses of steroids used in systemic therapy are typically lower than in PV, i.e. between 0.5 and $1.0 \mathrm{mg} / \mathrm{kgb} . \mathrm{w}$. of prednisone or prednisolone. Glucocorticosteroids should be combined with immunosuppressive drugs from the onset of treatment in cases of severe pemphigus and/ or increased risk of adverse effects due to chronic glucocorticosteroid therapy. According to the expert group consensus the first-line immunosuppressive drug which should be used in combination with prednisone is azathioprine at $1-3 \mathrm{mg} / \mathrm{kg}$ b.w./day. Second-line drugs used in the treatment of pemphigus include mycophenolate mofetil, anti-CD20 monoclonal antibodies (e.g. rituximab), intravenous immunoglobulins (IVIG), cyclophosphamide, dapsone, and in justified cases methylprednisolone [3].

The treatment of PF in children depends on the severity of the disease. Since PF is rare in this age group, there are no established therapeutic recommendations. In the majority of cases, similarly to adults, immunosuppressive treatment with glucocorticosteroids, azathioprine, mycophenolate mofetil, cyclophosphamide or rituximab is used [6].
17 lat, zgłasza się regularnie na wizyty kontrolne do przyklinicznej poradni dermatologicznej. Do marca 2016 r. nie stwierdzono nawrotu zmian o charakterze pęcherzycy liściastej.

\section{OMÓWIENIE}

Pęcherzyca liściasta u dzieci jest rzadką chorobą, która może sprawiać trudności diagnostyczne oraz terapeutyczne. Ze względu na powierzchowny charakter pęcherzy w obrazie klinicznym przeważają zmiany rumieniowo-złuszczające i płytkie nadżerki, w związku z czym diagnostyka różnicowa obejmuje m.in. liszajec zakaźny i łojotokowe zapalenie skóry [4]. W badaniu histopatologicznym poza obrębem właściwego pęcherza występują często szczeliny w warstwie ziarnistej, w których obecne są komórki akantolityczne o silnie barwliwych i pyknotycznych jądrach, co przypomina ziarna w chorobie Dariera. Nacieki zapalne w skórze właściwej są niewielkie, składają się głównie z leukocytów, częściowo eozynochłonnych [5]. W przedstawionym przypadku obraz histopatologiczny był trudny do interpretacji. Początkowo rozpoznano na jego podstawie chorobę Dariera. W opisie kolejnego wycinka skóry stwierdzano obecność akantolizy, parakeratozy, rozrostu naczyń brodawkowatych ze ścieńczeniem naskórka nad brodawkami oraz skupienie neutrofilów w wysięku na powierzchni z ogniskowo występującym częściowym odwarstwieniem górnych partii naskórka, co świadczyło o PF. Ostatecznie chorobę potwierdzono na podstawie wyników badań immunologicznych.

Lekami pierwszego rzutu w PF są glikokortykosteroidy. $W$ terapii ogólnej zwykle stosuje się mniejsze dawki steroidów niż w PV, tj. od 0,5 do 1,0 mg/ kg m.c. prednizonu lub prednizolonu. Glikokortykosteroidy powinny być kojarzone z lekami immunosupresyjnymi od początku terapii w przypadkach ciężkiej pęcherzycy i/lub w zwiększonego ryzyka wystąpienia działań niepożądanych związanych z przewlekłą glikokortykosteroidoterapią. Według grupy eksperckiej lekiem immunosupresyjnym pierwszego rzutu, który powinien być stosowany w połączeniu z prednizonem, jest azatiopryna (w dawce 1-3 mg/kg m.c./dobę). Do leków drugiego wyboru stosowanych w leczeniu pęcherzycy zalicza się: mykofenolan mofetylu, monoklonalne przeciwciała anty-CD20 (np. rytuksymab), dożylne immunoglobuliny (IVIG), cyklofosfamid, dapson, w uzasadnionych przypadkach metyloprednizolon [3].

Leczenie PF u dzieci zależy od nasilenia procesu chorobowego. Ze względu na rzadkie występowanie choroby w tej grupie wiekowej nie są ustalone jednoznaczne rekomendacje. W większości przypadków stosuje się, podobnie jak u osób dorosłych, leczenie immunosupresyjne z zastosowaniem glikokortykosteroidów, azatiopryny, mykofenolanu mofetylu, cyklofosfamidu lub rytuksymabu [6]. 
In the reported patient glucocorticosteroids were initiated as first-line treatment. Since monotherapy was unsuccessful, it was decided to use combination treatment with cyclophosphamide. One of the factors determining the decision was a previous case of PF in a child, where the same therapeutic regimen was followed, producing a good clinical outcome [7].

Literature reports on the treatment of PF in children are limited. Even though the clinical features of the disease in adults and children are similar, it does not seem appropriate to extrapolate therapeutic regimens from adults to the paediatric population [8]. It is important to report the outcome of treatment given to children in order to introduce clear recommendations on the most effective and safest therapies in the paediatric population.

There have been reports of paediatric patients achieving remission of the disease in response to systemic glucocorticosteroids without serious adverse effects $[9,10]$. However, systemic glucocorticosteroid therapy is associated with a high risk of adverse effects, especially in children. In this population prolonged glucocorticosteroid treatment may lead to growth arrest, and recurrences of the disease are often observed after the completion of treatment [11]. The literature contains a report of an 8-year-old boy who received oral glucocorticosteroid treatment. Owing to adverse drug reactions the treatment was discontinued, which led to the exacerbation of skin lesions. Dapsone was used as second-line treatment, however the child developed methemoglobinaemia in response to therapy. After the dose was reduced, normal methemoglobin levels and disease remission were achieved [12]. In a 7-year-old girl systemic glucocorticosteroids failed to produce the expected therapeutic effect, which is why combination treatment with prednisolone and dapsone was initiated. The regimen resulted in a rapid improvement of skin lesions. No adverse effects accompanying the treatment were reported [13]. Similarly, oral glucocorticosteroid therapy was shown to be insufficient in a 14-year-old girl with PF and noncicatricial alopecia. Azathioprine was added to the patient's treatment, but it was discontinued because of a sevenfold increase in liver aminotransferases above the limit of normal. Intravenous immunoglobulin infusions were administered as second-line immunosuppressive treatment, and immunopheresis was performed, producing a satisfactory clinical response [14]. In another literature report a girl received combination therapy with a glucocorticosteroid, azathioprine and sulphapyridin. The treatment was well-tolerated and resulted in remission of the disease [15]. Another therapeutic option in children, particularly with photosensitivity, may be hydroxychloroquine [4].
U przedstawianego pacjenta jako leczenie pierwszego rzutu włączono glikokortykosteroidy. W związku $\mathrm{z}$ nieskutecznością monoterapii zdecydowano o zastosowaniu leczenia skojarzonego z cyklofosfamidem. Decyzję podjęto m.in. na podstawie poprzedniego przypadku PF u dziecka, leczonego wg tego samego schematu. Uzyskano wówczas dobry efekt kliniczny [7].

Doniesienia w piśmiennictwie dotyczące leczenia PF u dzieci są ograniczone. Mimo występowania podobnych cech klinicznych u dorosłych i dzieci niewłaściwe wydaje się dokładne przekładanie schematów terapeutycznych zalecanych $\mathrm{u}$ dorosłych na populację dziecięcą [8]. Ważne jest przedstawianie efektów zastosowanego leczenia w celu wprowadzenia jednoznacznych zaleceń dotyczących najskuteczniejszej i najbezpieczniejszej terapii u dzieci.

Opisywani są pacjenci pediatryczni, u których zastosowanie glikokortykosteroidów systemowo wystarczyło do uzyskania remisji choroby przy braku poważnych działań niepożądanych [9, 10]. Glikokortykosteroidoterapia ogólna obarczona jest jednak dużym ryzykiem działań niepożądanych, zwłaszcza u dzieci. Długotrwała terapia w tej grupie może się wiązać m.in. z zahamowaniem wzrostu, a po jej zakończeniu często obserwuje się nawroty choroby [11]. W piśmiennictwie znajduje się opis przypadku 8-letniego chłopca, u którego zastosowano glikokortykosteroidy doustnie. Ze względu na działania niepożądane zdecydowano o ich odstawieniu, co spowodowało zaostrzenie zmian skórnych. Jako leczenie drugiego rzutu zastosowano dapson, po którym stwierdzono methemoglobinemię. Po zmniejszeniu dawki uzyskano prawidłowe wartości methemoglobiny i remisję choroby [12]. U 7-letniej dziewczynki zastosowanie glikokortykosteroidów systemowo nie przyniosło oczekiwanego rezultatu, w związku z czym zdecydowano o włączeniu leczenia skojarzonego prednizolonem i dapsonem. Pozwoliło to na uzyskanie szybkiej poprawy w zakresie zmian skórnych. Nie opisywano działań niepożądanych po leczeniu [13]. Podobnie u 14-letniej dziewczynki z PF oraz niebliznowaciejącą utratą włosów terapia doustnymi glikokortykosteroidami okazała się niewystarczająca. U tej pacjentki dołączono azatioprynę, którą odstawiono ze względu na siedmiokrotny powyżej normy wzrost stężenia aminotransferaz wątrobowych. Jako leczenie immunosupresyjne drugiego rzutu podano dożylne wlewy immunoglobulin oraz przeprowadzano immunoferezę z satysfakcjonującym efektem klinicznym [14]. Opisano także przypadek dziewczynki, u której terapia skojarzona glikokortykosteroidem, azatiopryną oraz sulfapirydyną była dobrze tolerowana i spowodowała remisję choroby [15]. Kolejną możliwością terapeutyczną dla dzieci, zwłaszcza z nadwrażliwością na światło, może być hydroksychlorochina [4].

$\mathrm{W}$ ostatnich latach $\mathrm{w}$ terapii pęcherzycy preferuje się rytuksymab ze względu na dobrą tolerancję leku oraz wysoką skuteczność. U 21-miesięcznej dziew- 
Rituximab has been preferred in the treatment of pemphigus in recent years because of its good tolerance and high efficacy. A 21-month-old girl diagnosed with PF was treated with systemic steroids, antibiotics, mycophenolate mofetil and intravenous immunoglobulin infusions, however it was not until rituximab infusions were administered that rapid clinical remission was achieved [16]. Since experience in the treatment of PF in the paediatric population is limited, further studies and long-term follow-up are necessary to gain new insights.

\section{CONCLUSIONS}

Immunologic tests are a necessary complement of the differential diagnosis of dermatoses in children - particularly in cases where the clinical and histopathological features are quite uncharacteristic, and no improvement is observed after treatment.

\section{ACKNOWLEDGMENTS}

The study has been financed from the statutory funds of the Medical University of Łódź, no. 503/1152-01/503-01 and 503/5-064-01/503-01.

\section{CONFLICT OF INTEREST}

The authors declare no conflict of interest. czynki z rozpoznaną PF, u której wcześniej stosowano steroidoterapię ogólną, antybiotykoterapię oraz mykofenolan mofetylu i dożylne wlewy immunoglobulin, dopiero zastosowanie wlewów rytuksymabu pozwoliło na szybkie uzyskanie remisji klinicznej [16]. Ze względu na nieliczne doświadczenia w terapii dzieci z PF konieczne są dalsze badania i długotrwałe obserwacje.

\section{WNIOSKI}

Badania immunologiczne są niezbędnym uzupełnieniem diagnostyki różnicowej dermatoz u dzieci, szczególnie w przypadku mało charakterystycznego obrazu klinicznego i histopatologicznego oraz braku poprawy po stosowanym leczeniu.

\section{PODZIĘKOWANIA}

Praca finansowana ze środków statutowych Uniwersytetu Medycznego w Łodzi nr 503/1-15201/503-01 oraz 503/5-064-01/503-01.

\section{KONFLIKT INTERESÓW}

Autorzy deklarują brak konfliktu interesów.

\section{References}

\section{Piśmienictwo}

1. Wolff K., Johnson R.A., Saavedra A.P.: Uwarunkowane genetycznie i nabyte choroby pęcherzowe. [In:] Fitzpatrik. Atlas i zarys dermatologii klinicznej. D. Krasowska (ed.), Czelej, Lublin, 2014, 1, 89-110.

2. Dmochowski M.: Pęcherzyca liściasta, pęcherzyca IgA. Pęcherzyca zwykła i pęcherzyca paraneoplastyczna. [In:] Autoimmunologiczne dermatozy pecherzowe. M. Dmochowski (ed.)., UM Poznań, Poznań, 2006, 28-115.

3. Kowalewski C., Dmochowski M., Placek W., Waszczykowska E., Nowicki R., Flisiak I., et al.: Diagnostyka i leczenie pęcherzycy - konsensus Polskiego Towarzystwa Dermatologicznego. Przegl Dermatol 2014, 101, 147-155.

4. Metry D.W., Hebert A.A., Jordon R.E.: Nonendemic pemphigus foliaceus in children. J Am Acad Dermatol $2002,46,419-422$.

5. Jabłońska S., Chorzelski T.: Choroby pęcherzowe. [In:] Histopatologia skóry. S. Jabłońska, T. Chorzelski (eds.), PZWL, Warsaw, 1965, 124.

6. Adah A., Hill K., Wyatt J., Didion L.: Pemphigus foliaceus in an adolescent. J Pediatr 2014, 165, 1062.

7. Narbutt J., Torzecka J.D., Sysa-Jedrzejowska A., Pas H.H.: Pemphigus foliaceus in an 11-year-old boy with dermatomyositis: simple coincidence or familial immunological background? Br J Dermatol 2003, 148, 838-839.

8. Marathe K., Lu J., Morel K.D.: Bullous diseases: kids are not just little people. Clin Dermatol 2015, 33, $644-656$.

9. Geller S., Gat A., Harel A., Mashiah J., Zeeli T., Eming R., et al.: Childhood pemphigus foliaceus with exclusive immunoglobulin G autoantibodies to desmocollins. Pediatr Dermatol 2016, 33, e10-e13.

10. Kanwar A.J., Dhar S., Kaur S.: Further experience with pemphigus in children. Pediatr Dermatol 1994, 11, 107-111.

11. Rosella M., Masia I.M., Satta R., Cottoni F.: Pemphigus foliaceus in a child. Pediatr Dermatol 1996, 13, 259-260.

12. Galambrun C., Cambazard F., Clavel C., Versini P., Stéphan J.L.: Pemphigus foliaceus. Arch Dis Child 1997, 77, $255-257$.

13. Mehravaran M., Morvay M., Molnár K., Oláh J., Korom I., Husz S., et al.: Juvenile pemphigus foliaceus. Br J Dermatol 1998, $139,496-499$.

14. Mlynek A., Bär M., Bauer A., Meurer M.: Juvenile pemphigus foliaceus associated with severe nonscarring alopecia. Br J Dermatol 2009, 161, 472-474.

15. Goodyear H.M., Abrahamson E.L., Harper J.I.: Childhood pemphigus foliaceus. Clin Exp Dermatol 1991, 16, 229-230.

16. Connelly E.A., Aber C., Kleiner G., Nousari C., Charles C., Schachner L.A.: Generalized erythrodermic pemphigus foliaceus in a child and its successful response to rituximab treatment. Pediatr Dermatol 2007, 24, 172-176.

How to cite this article

Salińska M., Trambowicz K., Narbutt J., Woźniacka A., Lesiak A.: Combination therapy with prednisone and cyclophosphamide in a 14-year-old boy with pemphigus foliaceus - a case report. Dermatol Rev/Przegl Dermatol 2017, 104, 324-330.

DOI: https://doi.org/10.5114/dr.2017.68779. 